\title{
Studi Perbandingan Alat Penukar Kalor Tipe Shell and Tube Tembaga-Aluminium Untuk Pitch Segiempat
}

\author{
Cahyono Heri P, A. Zayadi, Basori, Asmawi \\ Program Studi Teknik Mesin Fakultas Teknik dan Sains Universitas Nasional, Jakarta \\ tmesin_unas@yahoo.co.id
}

\begin{abstract}
ABSTRAK. Alat penukar kalor merupakan alat yang digunakan untuk memindahkan panas antara dua fluida atau lebih yang mempunyai temperatur yang berbeda. Dalam tugas akhir ini, dilakukan percobaan serta melakukan perhitungan terhadap hasil percobaan yang telah dilakukan. Hasil percobaan dan perhitungan menunjukkan bahwa dengan metode LMTD didapat laju perpindahan panas pada tube tembaga $\left(\mathrm{Q}_{\mathrm{cu}}\right)=427,5409$ watt lebih besar daripada laju perpindahan panas pada tube alumunium $\left(\mathrm{Q}_{\mathrm{al}}\right)=372,364$ Watt. Hal ini disebabkan oleh selisih temperature rata-rata pada alat penukar kalor dengan tube yang terbuat dari alumunium dan tembaga. Dengan metode NTU-efektivitas, menunjukkan bahwa laju perpindahan panas tube tembaga $\left(\mathrm{Q}_{\mathrm{cu}}\right)=527$ Watt lebih besar dibandingkan dengan tube Aluminium. Hal itu disebabkan oleh selisih temperatur rata-rata minimum pada alat penukar kalor dengan tube terbuat dari tembaga lebih besar dibandingkan dengan yang lain.
\end{abstract}

Kata kunci: Penukar kalor, shell and tube, pitch segiempat

\begin{abstract}
Heat exchanger is a device used to transfer heat between two fluids or more that have different temperatures. In this thesis, conducted experiments and perform calculations on the results of experiments that have been done. The results of experiments and calculations show that the LMTD method of heat transfer rate obtained on the copper tube $(Q c u)=427.5409$ watts is greater than the rate of heat transfer to the aluminum tube $($ Qal $)=372.364$ Watt. This is caused by the difference in the average temperature in a heat exchanger with a tube made of aluminum and copper. With NTU-effectiveness method, showed that the rate of heat transfer tube copper $(Q c u)=527$ Watt larger than the aluminum tube. It is caused by the difference in the average minimum temperature in a heat exchanger with a tube made of copper greater than others.
\end{abstract}

Keywords: heat exchanger, shel and tube, rectangular pitch

\section{PENDAHULUAN}

Di zaman yang modern ini ilmu pengetahuan dan teknologi berkembang semakin meningkat, terlebih di dalam bidang konversi energi. Krisis energi sedang dialami di negeri ini, oleh karena itu kita diharapkan dapat mencari energi alternative yang dapat menggantikan energi yang sudah ada. Selain mencari energi alternatif kita juga diharapkan dapat menghemat energi. Salah satu cara yang dapat dilakukan untuk menghemat penggunaan energi yaitu dengan cara menggunakan kembali energi panas yang terbuang atau dengan kata lain panas sisa yang seharusnya dibuang itu dapat juga digunakan.

Untuk melakukan perpindahan panas kita membutuhkan yang namanya alat penukar kalor. Alat penukar kalor adalah suatu peralatan proses yang digunakan untuk memindahkan panas dari dua fluida yang berbeda, dari fluida yang bersuhu yang lebih tinggi ke fluida yang bersuhu lebih rendah dimana perpindahan panas dapat terjadi secara langsung (kedua fluida kontak secara langsung) ataupun secara tidak langsung (dibatasi oleh suatu dinding/sekat). Pada alat penukar kalor jenis shell \& tube, perpindahan panas terjadi secara tidak langsung, karena fluida tidak kontak secara langsung.

Penerapan prinsip-prinsip perpindahan kalor untuk merancang (design) alat-alat guna mencapai suatu tujuan teknik sangatlah penting, karena dalam menerapkan prinsip ke dalam rancanganlah orang bekerja ke arah pencapaian tujuan untuk mengembangkan barang hasil yang memberikan manfaat ekonomi. Akhirnya ekonomi pulalah yang memegang peranan penting dalam 
perancangan dan pemilihan alat-alat penukar kalor, dan para ahli teknik tidak boleh melupakan ini setiap kali berhadapan dengan soal-soal baru dalam perancangan alat penukar kalor.

Pada penelitian alat penukar kalor shell \& tube memiliki tujuan untuk mempelajari design dan kinerja dan alat penukar kalor yang sudah ada. Selain itu dalam penelitian ini, dilakukan studi perbandingan yang didapat dari hasil penelitian. Dari studi tersebut dapat ditarik kesimpulan hasil mana yang lebih bagus dari hasil percobaan. Dengan merancang alat penukar kalor dengan skala laboratorium diharapkan mahasiswa dapat mengoperasikan dan mengerti fungsi dan cara kerja dari alat penukar kalor tersebut, sehingga dapat diaplikasikan dalam dunia kerja.

Dengan didapatkannya hasil perbaikan alat penukar kalor tipe shell \&tube diharapkan dapat menignkatkan suberdaya manusia di bidang konversi energi. Selain itu alat penukar kalor ini dapat dijadikan sebagai peralatan praktikum, agar mahasiswa lebih memahami dan dapat mengaplikasikan teori yang didapatkan dari kuliah.

\section{LANDASAN TEORI}

Perpindahan panas yaitu perpindahan energi yang terjadi karena adanya perbedaan suhu di antara benda atau material. Proses perpindahan energi tersebut berawal dari sistem yang bersuhu lebih tinggi ke sistem yang bersuhu lebih rendah. Energi yang pindah itu dinamakan kalor atau bahang atau panas (heat).

Dalam perpindahan panas, proses perpindahan energi tidak dapat diamati secara langsung tetapi pengaruhnya dapat diamati secara langsung. Teori perpindahan panas tidak hanya menjelaskan bagaimana energi panas tersebut berpindah dari satu benda ke benda lain, tetapi juga dapat meramalkan laju perpindahan yang terjadi pada kondisi-kondisi tertentu.

Alat penukar kalor setelah digunakan beberapa lama, permukaan perpindahan kalor penukar kalor mungkin dilapisi oleh berbagai endapan yang biasa terdapat dalam sistem aliran atau permukaan itu mungkin mengalami korosi sebagai akibat interaksi antara fluida dengan bahan yang digunakan dalam kostruksi penukar kalor. Dalam kedua hal di atas, lapisan itu memberikan tahanan tambahan terhadap aliran kalor, dan hal ini menyebabkan menurunnya kemampuan kerja alat itu. Pengaruh menyeluruh daripada hal tersebut di atas biasa dinyatakan dengan faktor pengotoran (fouling factor), atau tahanan pengotoran $\mathrm{R}_{\mathrm{f}}$, yang harus diperhitungkan bersama tahanan termal lainnya, dalam menghitung koefisien perpindahan kalor menyeluruh.

Faktor pengotoran harus didapatkan dari percobaan, yaitu dengan menentukan U untuk kondisi bersih dan kondisi kotor pada penukar kalor itu. Faktor pengotoran dapat didefinisikan sebagai

$$
R_{f}=\frac{1}{U_{\text {kotor }}}-\frac{1}{U_{\text {bersin }}}
$$

Dalam perhitungan alat penukar kalor ada dua metode perhitungan yaitu metode beda suhu ratarata (LMTD) dan metode NTU-efektivitas. Pendekatan LMTD dalam analisis penukar kalor berguna bila suhu masuk dan suhu keluar diketahui atau dapat ditentukan dengan mudah, sehingga LMTD dapat dengan mudah dihitung, dan aliran kalor, luas permukaan, dan koefisien perpindahan kalor menyeluruh dapat ditentukan.

Fluida dalam alat penukar kalor dapat mengalir sejajar atau berlawanan arah yang akan mempengaruhi perpindahan panas (kalor), maka perpindahan panas dengan rumus sebagai berikut

$$
q=U A \Delta T_{m}
$$

dimana:

$\mathrm{U}=$ koefisien perpindahan kalor menyeluruh

$A=$ luas permukaan perpindahan kalor yang sesuai dengan definisi $U$

$\Delta \mathrm{T}_{\mathrm{m}}=$ beda suhu rata-rata yang tepat untuk digunakan dalam penukar kalor atau beda temperatur pada satu ujung penukar kalor dikurangi beda temperatur pada ujung yang satu dibagi dengan logaritma dari perbandingan kedua beda temperatur tersebut. 


$$
\Delta T_{m}=\frac{\left(T_{h 2}-T_{c 2}\right)-\left(T_{h 1}-T_{c 1}\right)}{\ln \left[\left(T_{h 2}-T_{c 2}\right) /\left(T_{h 1}-T_{c 1}\right)\right]}
$$

Penurunan LMTD di atas menyangkut dua pengandaian : (1) kalor spesifik fluida tidak berubah menurut suhu, dan (2) koefisien perpindahan kalor konveksi tetap untuk seluruh penukar kalor. Andaian kedua ini biasanya sangat penting pengaruh pintu masuk, viskositas fluida, perubahan konduktivitas termal, dan sebagainya. Jika suatu penukar kalor yang bukan jenis pipa ganda digunakan, perpindahan kalor dihitung dengan menerapkan faktor koreksi terhadap LMTD untuk susunan pipa ganda aliran lawan arah dengan suhu fluida panas dan suhu fluida dingin yang sama. Bentuk persamaan perpindahan kalor menjadi:

$$
q=U A F \Delta T_{m}
$$

Faktor koreksi berdasarkan jenis aliran ( = 1 untuk pendidihan/kondensasi) adalah sebagai berikut :

- Faktor koreksi untuk alat penukar kalor dengan satu lintasan selongsong (cangkang) dan 2, 4 atau masing-masing kelipatan dari lintasan tabung (tube).

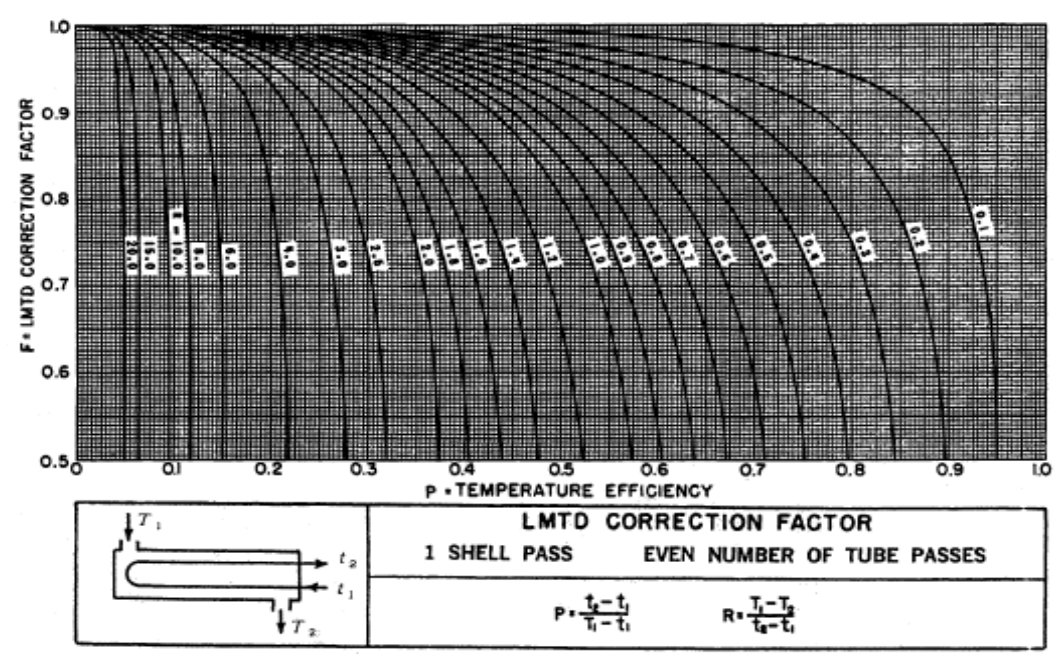

GAMBAR 1. Grafik Faktor koreksi untuk alat penukar kalor dengan satu lintasan selongsong (cangkang) masingmasing kelipatan dari lintasan tabung (tube).

- Faktor koreksi untuk alat penukar kalor dengan dua lintasan selongsong (cangkang) dan 4, 8 atau masing-masing kelipatan dari lintasan tabung (tube).

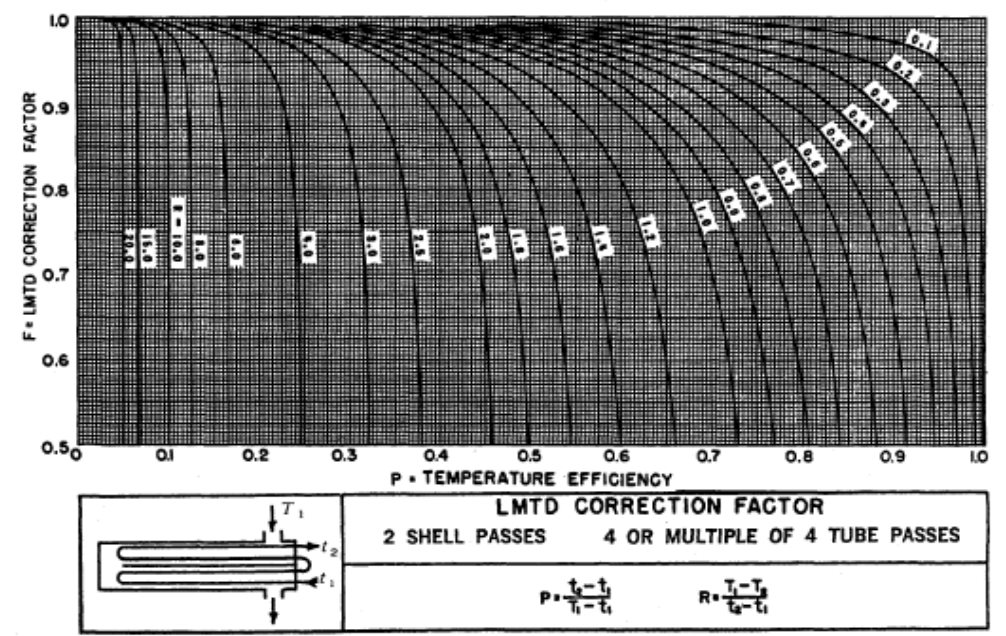

GAMBAR 2. Faktor koreksi untuk alat penukar kalor dengan dua lintasan selongsong (cangkang) dan masingmasing kelipatan dari lintasan tabung (tube). 
Bila temperatur masuk dan keluar sulit ditentukan, maka digunakan parameter lain. Ada dua parameter yang berhubungan dengan perancangan dan analisis alat penukar kalor, yaitu efektivitas dan NTU (number of transfer units). Efektivitas alat penukar kalor didefinisikan sebagai :

$$
\varepsilon=\frac{\text { perpindahan panas nyata }}{\text { perpindahan panas maksimum yang mungkin }}
$$

Perpindahan panas nyata adalah berdasarkan panas yang dilepaskan oleh fluida panas atau panas yang diterima oleh fluida dingin. Perpindahan panas nyata untuk aliran searah adalah

$$
q=\dot{m}_{h} C_{h}\left(T_{h 1}-T_{h 2}\right)=\dot{m}_{h} C_{h}\left(T_{c 2}-T_{c 1}\right)
$$

Perpindahan panas nyata untuk aliran berlawanan adalah:

$$
q=\dot{m}_{h} C_{h}\left(T_{h 1}-T_{h 2}\right)=\dot{m}_{h} C_{h}\left(T_{c 1}-T_{c 2}\right)
$$

Perpindahan panas maksimum ditentukan berdasarkan analisis bila terjadi perbedaan yang besar antara temperatur masuk fluida panas dan dingin dan bila nilai $\mathrm{m} \mathrm{c}$ berharga minimum (m c disebut laju kapasitas). Maka perpindahan panas maksimum yang mungkin adalah:

$$
q_{\text {maks }}=(\dot{m} c)_{\min }\left(T_{h \text { masuk }}-T_{c \text { masuk }}\right)
$$

Perpindahan panas minimum dapat terjadi pada fluida yang panas atau dingin, tergantung dari laju kapasitas atau tergantung dari laju alir massa dan panas spesifik / jenis.

Untuk aliran searah:

Fluida panas yang memiliki nilai $\mathrm{mc}_{\text {minimum }}$ :

$$
\varepsilon_{h}=\frac{\dot{m}_{h} c_{h}\left(T_{h 1}-T_{h 2}\right)}{\dot{m}_{h} c_{h}\left(T_{h 1}-T_{c 1}\right)}=\frac{T_{h 1}-T_{h 2}}{T_{h 1}-T_{c 1}}
$$

Fluida dingin yang memiliki nilai $\mathrm{mc}_{\text {minimum }}$ :

$$
\varepsilon_{C}=\frac{\dot{m}_{c} c_{C}\left(T_{C 2}-T_{C 1}\right)}{\dot{m}_{c} c_{C}\left(T_{h 1}-T_{C 1}\right)}=\frac{T_{C 2}-T_{C 1}}{T_{h 1}-T_{C 1}}
$$

Untuk aliran berlawanan :

Fluida panas yang memiliki nilai $\mathrm{mc}_{\text {minimum }}$ :

$$
\varepsilon_{h}=\frac{\dot{m}_{h} c_{h}\left(T_{h 1}-T_{h 2}\right)}{\dot{m}_{h} c_{h}\left(T_{h 1}-T_{c 2}\right)}=\frac{T_{h 1}-T_{h 2}}{T_{h 1}-T_{c 2}}
$$

Fluida dingin yang memiliki nilai $\mathrm{mc}_{\text {minimum }}$ :

$$
\varepsilon_{c}=\frac{\dot{m}_{c} c_{C}\left(T_{C 1}-T_{c 2}\right)}{\dot{m}_{c} c_{c}\left(T_{h 1}-T_{c 2}\right)}=\frac{T_{c 1}-T_{c 2}}{T_{h 1}-T_{c 2}}
$$

Secara umum efektivitas dinyatakan sebagai berikut :

$$
\varepsilon=\frac{\Delta T(\text { fluida minimum })}{\text { beda temperatur maksimum dalam } A P K}
$$

maka untuk aliran searah berlaku : 


$$
\varepsilon=\frac{1-\exp \left[\left(-U A / C_{\min }\right)\left(1+C_{\min } / C_{\operatorname{maks}}\right)\right]}{1+C_{\min } / C_{\operatorname{maks}}}
$$

dan untuk aliran berlawanan berlaku :

$$
\varepsilon=\frac{1-\exp \left[\left(-U A / C_{\min }\right)\left(1-C_{\min } / C_{\operatorname{maks}}\right)\right]}{1-\left(C_{\min } / C_{\operatorname{maks}}\right) \exp \left[\left(-U A / C_{\min }\right)\left(1-C_{\min } / C_{\operatorname{maks}}\right)\right]}
$$

Dimana,

$\mathrm{C}=\dot{m} c=$ laju kapasitas

$\mathrm{UA} / \mathrm{C}_{\min }=$ jumlah satuan perpindahan (NTU, number of transfer units) yang mengindikasikan sebagai ukuran penukar kalor.

\section{TAHAPAN PERANCANGAN DAN PENGUJIAN}

Komponen-komponen utama yang terdapat pada alat penukar kalor in adalah heater, pompa sirkulasi, valve, flowmeter, dan tube yang berada di dalam shell. Dalam pengujian ini pompa yang digunakan adalah pompa sirkulasi. Pompa digunakan untuk mengalirkan fluida dingin dari bak penampung menuju shell laluan. Diagram alir proses pengujian alat penukar kalor tipe shell and tube dengan aliran berlawanan ditunjukkan oleh gambar 3 .

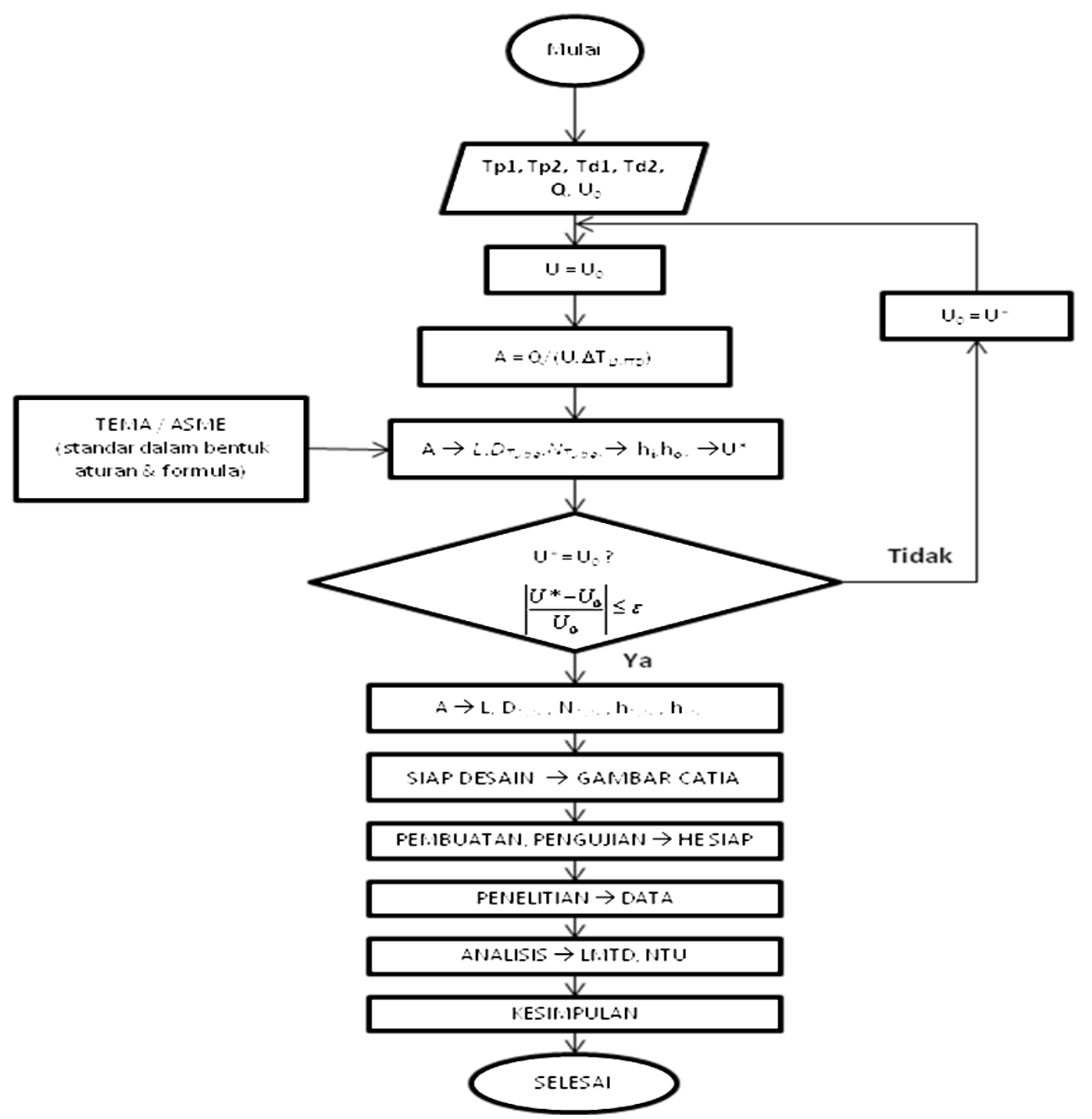

GAMBAR 3. Diagram alir proses pembuatan dan pengujian alat penukar kalor tipe shell and tube dengan aliran berlawanan. 


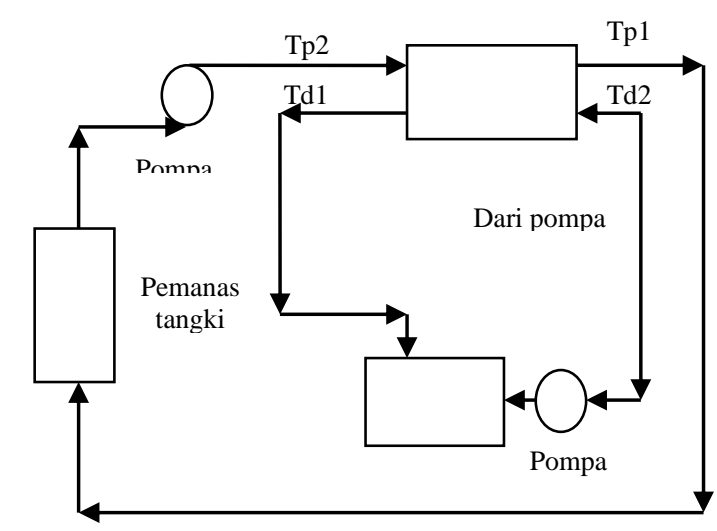

GAMBAR 4. Diagram blok alat penukar kalor tipe shell and tube.

Sebelum melakukan perhitungan, ada beberapa data yang harus didapatkan. Data yang dibutuhkan pada sisi shell adalah diameter dalam dari shell, jarak antar baffle, dan jumlah laluan. Sedangkan data yang dibutuhkan pada sisi tube adalah jumlah dan panjang dari tube, diameter dalam dan diameter luar dari tube, pitch, dan jumlah laluan. Pada fluida panas pada tube, suhu rata-rata aliran fluida panas dalam tube $\left(\mathrm{T}_{\mathrm{c}}\right)$

$$
T_{c t}=\frac{T_{p 1}+T_{p 2}}{2}
$$

Luas aliran fluida $\left(\mathrm{A}_{\mathrm{t}}\right)$

$$
A_{t}=\frac{N_{t} \cdot A}{144 \cdot n}
$$

Dimana :

$\mathrm{N}_{\mathrm{t}}=$ jumlah tube

$A=$ luas aliran tiap tube $\left(\mathrm{m}^{2}\right)$

$\mathrm{n}=$ jumlah laluan

dengan kecepatan alir fluida panas $\left(\mathrm{v}_{\mathrm{p}}\right)$ adalah:

$$
v_{p}=\frac{V_{p}}{A}
$$

Dimana :

$\mathrm{v}_{\mathrm{p}}=$ kecepatan alir fluida panas $(\mathrm{m} / \mathrm{s})$

$\mathrm{V}_{\mathrm{p}}=$ debit fluida panas $\left(\mathrm{m}^{3} / \mathrm{s}\right)$

Kecepatan aliran massa $\left(\mathrm{G}_{\mathrm{t}}\right)$

$$
G_{t}=v_{p} \rho
$$

dengan bilangan Reynolds adalah:

$$
R e_{t}=\frac{(I D / 12)}{\mu_{t}} \cdot G_{t}
$$

Dimana :

$\mathrm{ID}=$ diameter dalam tube $(\mathrm{m})$

$\mathrm{G}_{\mathrm{t}}=$ kecepatan aliran massa $\left(\mathrm{kg} / \mathrm{m}^{2} . \mathrm{s}\right)$

Bilangan Prandtl

$$
P r_{t}=\frac{C p \cdot \mu_{t}}{k}
$$


Dimana :

$\mathrm{Cp}=$ Kapasitas panas fluida di tube $\left(\mathrm{J} / \mathrm{kg} .{ }^{0} \mathrm{C}\right)$

$\mathrm{K}=$ konduktivitas fluida di tube $\left(\mathrm{W} / \mathrm{m} .{ }^{0} \mathrm{C}\right)$

Bilangan Nusselt

$$
N u=1,86 \cdot \operatorname{Re}_{t}^{0,33} \cdot \operatorname{Pr}_{t}^{0,33}\left(\frac{I D}{L}\right)^{0,33}\left(\frac{\mu}{\mu_{w}}\right)^{0,14}
$$

Koefisien perpindahan panas di tube

$$
h_{i}=\frac{N u \cdot k}{I D}
$$

Pressure drop pada sisi tube

$$
\Delta P_{t}=\frac{f_{t} \cdot G_{t}{ }^{2} \cdot L \cdot n}{2 g \rho(I D / 12)}
$$

Untuk fluida dingin pada shell, suhu rata-rata aliran fluida dingin dalam shell $\left(\mathrm{T}_{\mathrm{c}}\right)$

$$
T_{C S}=\frac{T_{d 1}+T_{d 2}}{2}
$$

Luas aliran fluida dingin $\left(\mathrm{A}_{\mathrm{s}}\right)$

$$
A_{S}=\frac{I D \cdot C \cdot B}{144 . P_{T}}
$$

Dimana :

$\mathrm{A}_{\mathrm{s}}=$ luas aliran fluida dingin $\left(\mathrm{m}^{2}\right)$

$\mathrm{ID}=$ diameter dalam shell $(\mathrm{m})$

$\mathrm{C}=$ daerah bebas antar tube $(\mathrm{m})$

$\mathrm{B}=$ jarak antar baffle $(\mathrm{m})$

$\mathrm{P}_{\mathrm{T}}=$ jarak antar tube $(\mathrm{m})$

dengan kecepatan alir fluida dingin $\left(\mathrm{v}_{\mathrm{d}}\right)$

Dimana :

$$
v_{d}=\frac{V_{d}}{A_{s}}
$$

$\mathrm{V}_{\mathrm{d}}=$ kecepatan alir fluida dingin $(\mathrm{m} / \mathrm{s})$

$\mathrm{V}_{\mathrm{d}}=$ debit fluida dingin $\left(\mathrm{m}^{3}\right)$

Kecepatan aliran massa $\left(\mathrm{G}_{\mathrm{d}}\right)$

$$
G_{d}=v_{d} \cdot \rho
$$

Diameter ekivalen

$$
D_{e}=\frac{4\left(P_{T}{ }^{2}-\pi \cdot O D^{2} / 4\right)}{\pi . O D}
$$

Dimana :

$\mathrm{D}_{\mathrm{e}}=$ diameter ekivalen $(\mathrm{m})$

$\mathrm{OD}=$ diameter luar tube $(\mathrm{m})$

Bilangan Reynolds

$$
R e_{s}=\frac{D_{e} \cdot G_{s}}{\mu_{s}}
$$


Bilangan Prandtl

$$
P r_{s}=\frac{C p \cdot \mu_{s}}{k}
$$

Dimana :

$\mathrm{Cp}=$ Kapasitas panas fluida di shell $\left(\mathrm{J} / \mathrm{kg} .{ }^{0} \mathrm{C}\right)$

$\mathrm{K}=$ konduktivitas fluida di shell $\left(\mathrm{W} / \mathrm{m} .{ }^{\circ} \mathrm{C}\right)$

Bilangan nusselt

$$
\mathbb{N} u_{s}=0,36 \cdot \operatorname{Re}_{s}^{0,55}{ }_{{ }_{0}} P_{s}^{0,33}\left(\frac{\mu}{\mu_{w}}\right)^{0,14}
$$

Koefisien perpindahan panas di shell

$$
h_{o}=0,36 \frac{k}{D_{e}} R_{e}^{0,55} \cdot P r_{s}^{0,33}
$$

Pressure drop pada sisi tube

$$
\Delta P_{S}=\frac{\left\{f_{s} \cdot G_{S}^{2} \cdot(I D / 12) \cdot(N+1)\right\}}{2 \cdot g \cdot \rho \cdot D_{e} \cdot \Phi_{S}}\left(N_{S}\right)
$$

Koefisien perpindahan panas menyeluruh (U)

$$
U=\frac{1}{\frac{1}{h_{i}}+\frac{A_{i} \ln \left(r_{O} / r_{i}\right)}{2 \pi k L}+\frac{A_{i} 1}{A_{O} h_{O}}}
$$

Laju perpindahan panas

$$
Q=C \min . \Delta T 0
$$

NTU (Number Transfer Unit)

$$
N T U=\frac{A \cdot U}{C \min }
$$

\section{ANALISA DATA DAN PEMBAHASAN}

\section{Hasil Perhitungan untuk Tube Aluminium}

Pada tabel 1. memperlihatkan data-data yang diperoleh dari hasil percobaan dalam aliran berlawanan pada tube aluminium pada alat penukar kalor tipe shell and tube.

TABEL 1. Data dari hasil percobaan untuk tube aluminium.

\begin{tabular}{|c|l|l|l|l|l|}
\hline No. & \multicolumn{1}{|c|}{ Uraian } & Simbol & \multicolumn{1}{c|}{ Shell } & \multicolumn{1}{c|}{ Tube } & Satuan \\
\hline 1. & Fluida masuk & $\mathrm{T}_{\text {in }}$ & 28 & 44 & ${ }^{0} \mathrm{C}$ \\
\hline 2. & Fluida keluar & $\mathrm{T}_{\text {out }}$ & 32 & 36 & ${ }^{0} \mathrm{C}$ \\
\hline 3. & Selisih suhu & $\Delta \mathrm{T}$ & 4 & 8 & ${ }^{0} \mathrm{C}$ \\
\hline 4. & $\begin{array}{l}\text { Kapasitas } \\
\text { panas }\end{array}$ & $\mathrm{Cp}$ & 4176 & 4174 & $\mathrm{~J} / \mathrm{kg}{ }^{0} \mathrm{C}$ \\
\hline 5. & Viskositas & $\mu$ & 0.000803 & 0.000656 & $\mathrm{~kg} / \mathrm{m} . \mathrm{s}$ \\
\hline 6. & $\begin{array}{l}\text { Konduktivitas } \\
\text { panas }\end{array}$ & $\mathrm{k}$ & 0.6248 & 0.633 & $\mathrm{~W} / \mathrm{m}^{0} \mathrm{C}$ \\
\hline 7. & Densitas & $\rho$ & 995.26 & 992.04 & $\mathrm{~kg} / \mathrm{m}^{3}$ \\
\hline
\end{tabular}


Tipe alat penukar kalor yang akan diuji adalah tipe shell and tube, dimana jenis alirannya adalah berlawanan, dengan 16 aliran di tube dab 1 laluan di shell. Besarnya laju perpindahan panas yang diperoleh dari pemanas sebesar 3000 watt, dengan asumsi tidak ada panas yang keluar maupun masuk pada dinding tangki pemanas.

Harga koefisien perpindahan panas yang akan dihitung sudah termasuk faktor pengotoran, konduktivitas termal, koefisien perpindahan panas pada shell dan tube. Air yang digunakan dalam percobaan ini adalah air tanah.

TABEL 2. Selisih temperatur untuk aliran berlawanan pada tube aluminium untuk alat penukar kalor tipe shell and tube.

\begin{tabular}{|c|c|c|c|}
\hline No. & $\begin{array}{c}\text { Fluida panas } \\
\left({ }^{0} \mathrm{C}\right)\end{array}$ & $\begin{array}{c}\text { Fluida dingin } \\
\left({ }^{\circ} \mathrm{C}\right)\end{array}$ & $\begin{array}{c}\text { Selisih suhu } \\
\left({ }^{0} \mathrm{C}\right)\end{array}$ \\
\hline 1 & 44 & 28 & 16 \\
\hline 2 & 36 & 32 & 4 \\
\hline
\end{tabular}

TABEL 3. Dimensi alat penukar kalor untuk aliran berlawanan pada aluminium untuk alar penukar kalor tipe shell and tube.

\begin{tabular}{|c|c|c|}
\hline No. & Uraian & Dimensi \\
\hline 1. & $\begin{array}{l}\text { SHELL } \\
\text { Diameter dalam } \\
\text { Diameter luar }\end{array}$ & $\begin{array}{l}0,11 \mathrm{~m} \\
0,12 \mathrm{~m}\end{array}$ \\
\hline 2. & $\begin{array}{l}\text { TUBE } \\
\text { Diameter dalam } \\
\text { Diameter luar } \\
\end{array}$ & $\begin{array}{l}0,006 \mathrm{~m} \\
0,008 \mathrm{~m} \\
\end{array}$ \\
\hline & $\begin{array}{l}\text { Jumlah tube } \\
\text { Jarak antar tube }\end{array}$ & $\frac{16}{0.02 \mathrm{~m}}$ \\
\hline 3. & $\begin{array}{l}\text { Tebal tube } \\
\text { Panjang tube }\end{array}$ & $\begin{array}{l}0.001 \mathrm{~m} \\
1.5 \mathrm{~m}\end{array}$ \\
\hline 4. & $\begin{array}{l}\text { Jarak antar sekat } \\
\text { jumlah sekat }\end{array}$ & $\begin{array}{l}0,125 \mathrm{~m} \\
10\end{array}$ \\
\hline 5. & $\begin{array}{l}\text { Laluan } \\
\text { Pada pipa (tube) } \\
\text { Pada pipa (shell) }\end{array}$ & $\begin{array}{l}1 \text { laluan } \\
1 \text { laluan }\end{array}$ \\
\hline
\end{tabular}

Dari tabel 1 dan 2. dapat dilihat dalam grafik perubahan suhu pada temperatur (T) panas (Tp1), untuk Tp1 temperatur awal masuk (t) 0 menit sebesar $65{ }^{\circ} \mathrm{C}$ dan pada $\mathrm{Tp} 2$ temperatur awal masuk (t) 0 menit sebesar $37{ }^{\circ} \mathrm{Cdan}$ untuk temperatur suhu Tp1 dan Tp2 mengalami penurunan suhu sampai mencapai suhu konstan, untuk Tp1 mengalami penurunan suhu sampai $44{ }^{\circ} \mathrm{C}$ pada waktu (t) 30 menit dan untuk Tp2 mengalami penurunan suhu sampai $36^{\circ} \mathrm{C}$ pada waktu (t) 10 menit.

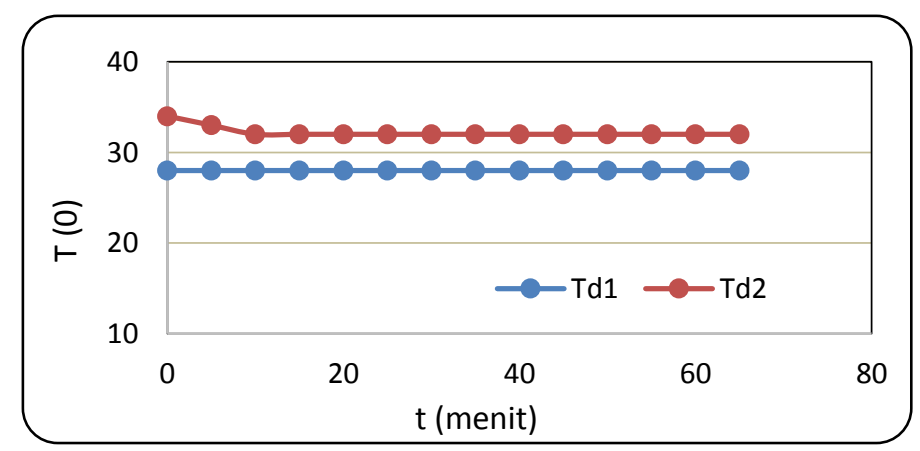

GAMBAR 5. Grafik temperatur fuida dingin masuk (Td1) dan keluar (Td2) sebagai fungsi waktu (t) pada tube aluminium. 
Dari gambar 5 dapat dilihat dalam grafik terjadi perubahan temperatur $(\mathrm{T})$ dingin $(\mathrm{Td})$, untuk Td1 temperatur awal masuk pada menit ke 0 adalah $28{ }^{\circ} \mathrm{C}$ dan $\mathrm{Td} 2$ temperatur keluar pada menit ke 0 adalah $34{ }^{\circ} \mathrm{C}$. Td1 tidak mengalami perubahan temperatur dan $\mathrm{Td} 2$ mengalami penurunan temperatur sampai temperatur $32{ }^{\circ} \mathrm{C}$ hingga konstan pada menit ke 10.

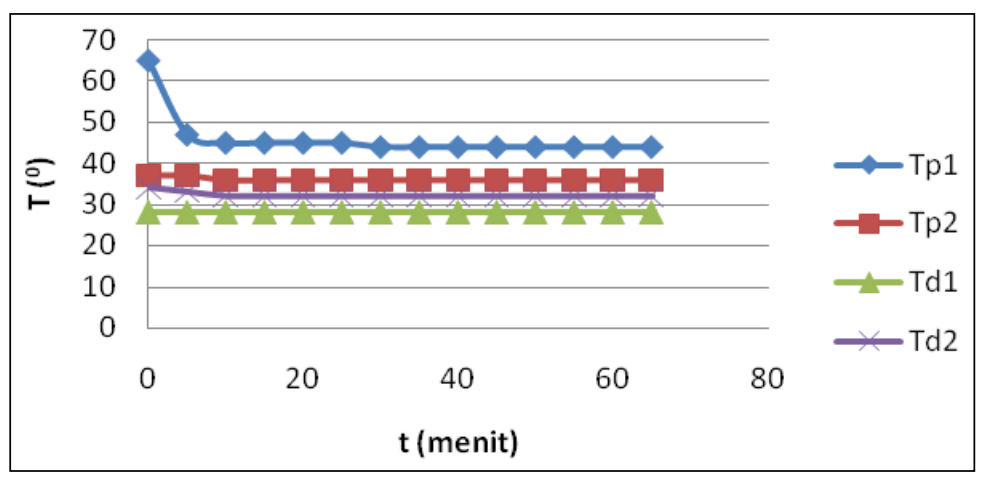

GAMBAR 6. Temperatur fluida panas masuk (Tp1), fluida panas keluar (Tp2), fluida dingin masuk (Td1), dan fluida dingin keluar (Td2) sebagai fungsi waktu (t) pada tube aluminium.

Dari gambar 6 dapat dilihat dalam grafik perubahan suhu pada temperatur $(\mathrm{T})$ panas $(\mathrm{Tp})$, untuk Tp1 temperatur awal masuk (t) 0 menit sebesar $65^{\circ} \mathrm{C}$, Td1 temperatur awal masuk (t) 0 menit sebesar $28{ }^{\circ} \mathrm{C}$, pada Tp2 temperatur awal masuk (t) 0 menit sebesar $37{ }^{\circ} \mathrm{C}$ dan pada $\mathrm{Td} 2$ temperatur awal masuk (t) 0 menit sebesar $34{ }^{\circ} \mathrm{C}$. Untuk temperatur suhu Tp1, Tp2, Td1, dan $\mathrm{Td} 2$ mengalami penurunan suhu konstan untuk Tp1 mengalami penurunan suhu sampai $44{ }^{\circ} \mathrm{C}$ pada menit ke 30, Tp2 mengalami penurunan suhu sampai $36{ }^{\circ} \mathrm{C}$ pada menit ke $10, \mathrm{Td} 2$ mengalami penurunan suhu sampai $32{ }^{\circ} \mathrm{C}$ pada menit ke 10 , dan pada $\mathrm{Td} 1$ mengalami suhu konstan.

\section{Hasil Perhitungan untuk Tube Tembaga}

Pada tabel 4 memperlihatkan data-data yang diperoleh dari hasil percobaan dalam aliran berlawanan pada tube tembaga pada alat penukar kalor tipe shell and tube.

TABEL 4. Data dari hasil percobaan untuk tube tembaga.

\begin{tabular}{|c|l|c|c|c|c|}
\hline No. & \multicolumn{1}{|c|}{ Uraian } & Simbol & Shell & Tube & Satuan \\
\hline 1. & Fluida masuk & $\mathrm{T}_{\text {in }}$ & 28 & 44 & ${ }^{0} \mathrm{C}$ \\
\hline 2. & Fluida keluar & $\mathrm{T}_{\text {out }}$ & 29 & 36 & ${ }^{0} \mathrm{C}$ \\
\hline 3. & Selisih suhu & $\Delta \mathrm{T}$ & 1 & 8 & ${ }^{0} \mathrm{C}$ \\
\hline 4. & Kapasitas panas & $\mathrm{Cp}$ & 4177 & 4174 & $\mathrm{~J} / \mathrm{kg}^{0} \mathrm{C}$ \\
\hline 5. & Viskositas & $\mu$ & 0.000829 & 0.000656 & $\mathrm{~kg} / \mathrm{m} . \mathrm{s}$ \\
\hline 6. & Konduktivitas panas & $\mathrm{k}$ & 0.6248 & 0.633 & $\mathrm{~W} / \mathrm{m}^{0} \mathrm{C}$ \\
\hline 7. & Densitas & $\rho$ & 995.5 & 992.04 & $\mathrm{~kg} / \mathrm{m}^{3}$ \\
\hline
\end{tabular}

\section{Tipe Alat Penukar Kalor dan Jenis Aliran}

Tipe alat penukar kalor yang akan diuji adalah tipe shell and tube, dimana jenis alirannya adalah berlawanan, dengan 16 aliran di tube dab 1 laluan di shell.

\section{Menentukan Laju Perpindahan Panas}

Besarnya laju perpindahan panas yang diperoleh dari pemanas sebesar 3000 watt, dengan asumsi tidak ada panas yang keluar maupun masuk pada dinding tangki pemanas.

\section{MenentukanKoefisien Perpindahan Panas Keseluruhan}

Harga koefisien perpindahan panas yang akan dihitung sudah termasuk faktor pengotoran, konduktivitas termal, koefisien perpindahan panas pada shell dan tube. Air yang digunakan dalam percobaan ini adalah air tanah. 
TABEL 5. Selisih temperatur untuk aliran berlawanan pada tube tembaga untuk alat penukar kalor tipe shell and tube.

\begin{tabular}{|c|c|c|c|}
\hline No. & $\begin{array}{c}\text { Fluida panas } \\
\left({ }^{\mathbf{0}} \mathbf{C}\right)\end{array}$ & $\begin{array}{c}\text { Fluida dingin } \\
\left({ }^{\mathbf{0}} \mathbf{C}\right)\end{array}$ & $\begin{array}{c}\text { Selisih suhu } \\
\left({ }^{\mathbf{0}} \mathbf{C}\right)\end{array}$ \\
\hline 1 & 44 & 28 & 16 \\
\hline 2 & 36 & 29 & 7 \\
\hline
\end{tabular}

TABEL 6. Dimensi alat penukar kalor untuk aliran berlawanan pada tembaga untuk alar penukar kalor tipe shell and tube.

\begin{tabular}{|c|c|c|}
\hline No. & Uraian & Dimensi \\
\hline \multirow{3}{*}{1} & SHELL & \\
\hline & Diameter dalam & $0,11 \mathrm{~m}$ \\
\hline & Diameter luar & $0,12 \mathrm{~m}$ \\
\hline \multirow{3}{*}{2} & TUBE & \\
\hline & Diameter dalam & $0,006 \mathrm{~m}$ \\
\hline & Diameter luar & $0,008 \mathrm{~m}$ \\
\hline \multirow{4}{*}{3} & Jumlah tube & 16 \\
\hline & Jarak antar tube & $0,02 \mathrm{~m}$ \\
\hline & Tebal tube & $0.001 \mathrm{~m}$ \\
\hline & Panjang tube & $1.5 \mathrm{~m}$ \\
\hline \multirow{2}{*}{4} & Jarak antar sekat & $0,125 \mathrm{~m}$ \\
\hline & jumlah sekat & 10 \\
\hline \multirow{3}{*}{5} & Laluan & \\
\hline & Pada pipa (tube) & 1 laluan \\
\hline & Pada pipa (shell) & 1 laluan \\
\hline
\end{tabular}

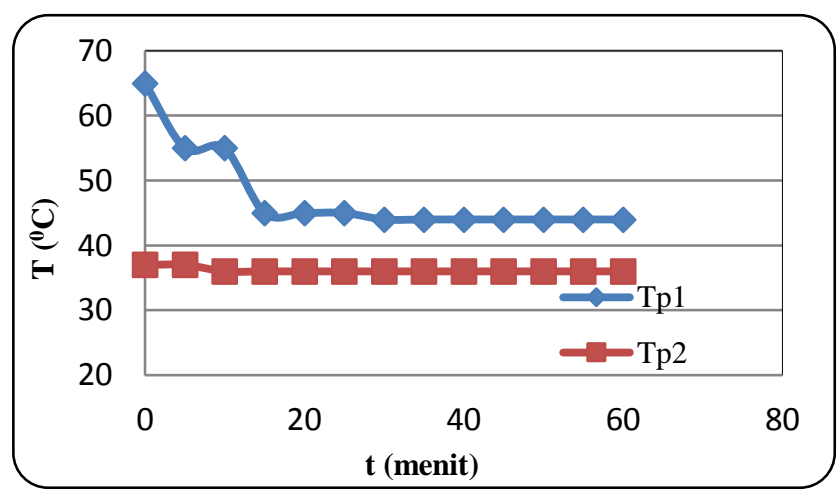

GAMBAR 7. Grafik untuk fluida panas masuk (Tp1) dan keluar (Tp2) sebagai fungsi waktu (t) pada tube tembaga.

Dari tabel 1 dan 2 dapat dilihat dalam grafik perubahan suhu pada temperatur (T) panas (Tp1), untuk Tp1 temperatur awal masuk (t) 0 menit sebesar $65{ }^{\circ} \mathrm{C}$ dan pada $\mathrm{Tp} 2$ temperatur awal masuk (t) 0 menit sebesar $37{ }^{\circ} \mathrm{Cdan}$ untuk temperatur suhu Tp1 dan Tp2 mengalami penurunan suhu sampai mencapai suhu konstan, untuk Tp1 mengalami penurunan suhu sampai $44{ }^{\circ} \mathrm{C}$ pada waktu (t) 25 menit dan untuk Tp2 mengalami penurunan suhu sampai $36^{\circ} \mathrm{C}$ pada waktu (t) 10 menit. 


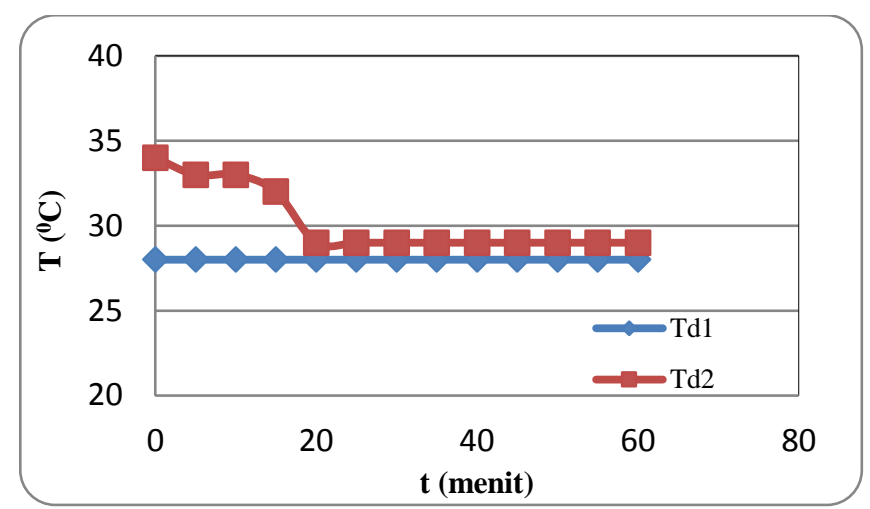

GAMBAR 8. Grafik temperatur fuida dingin masuk (Td1) dan keluar (Td2) sebagai fungsi waktu (t) pada tube tembaga.

Dari gambar 5 dapat dilihat dalam grafik terjadi perubahan temperatur (T) dingin (Td), untuk Td1 temperatur awal masuk pada menit ke 0 adalah $28{ }^{\circ} \mathrm{C}$ dan $\mathrm{Td} 2$ temperatur keluar pada menit ke 0 adalah $29{ }^{\circ} \mathrm{C}$. Td1 tidak mengalami perubahan temperatur dan $\mathrm{Td} 2$ mengalami penurunan temperatur sampai temperatur $29^{\circ} \mathrm{C}$ hingga konstan pada menit ke 10.

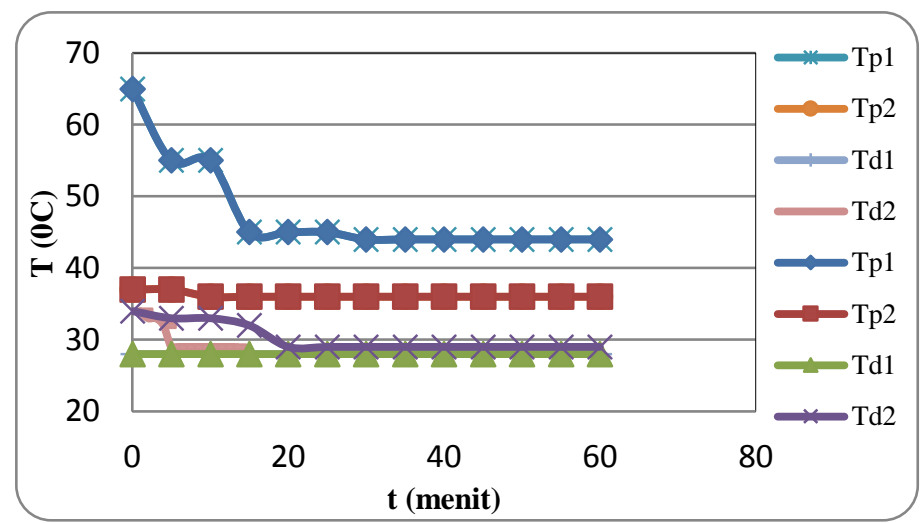

GAMBAR 9. Temperatur fluida panas masuk (Tp1), fluida panas keluar (Tp2), fluida dingin masuk (Td1), dan fluida dingin keluar (Td2) sebagai fungsi waktu (t) pada tube tembaga.

Dari gambar 9 dapat dilihat dalam grafik perubahan suhu pada temperatur (T) panas (Tp), untuk Tp1 temperatur awal masuk (t) 0 menit sebesar $65^{\circ} \mathrm{C}$, Td1 temperatur awal masuk (t) 0 menit sebesar $28{ }^{\circ} \mathrm{C}$, pada $\mathrm{Tp} 2$ temperatur awal masuk (t) 0 menit sebesar $37{ }^{\circ} \mathrm{C}$ dan pada $\mathrm{Td} 2$ temperatur awal masuk (t) 0 menit sebesar $34{ }^{\circ} \mathrm{C}$.

Untuk temperatur suhu Tp1, Tp2, Td1, dan Td2 mengalami penurunan suhu konstan untuk Tp1 mengalami penurunan suhu sampai $44{ }^{\circ} \mathrm{C}$ pada menit ke 30 , Tp2 mengalami penurunan suhu sampai $36{ }^{\circ} \mathrm{C}$ pada menit ke $10, \mathrm{Td} 2$ mengalami penurunan suhu sampai $29{ }^{\circ} \mathrm{C}$ pada menit ke 10, dan pada Td1 mengalami suhu konstan.

\section{PEMBAHASAN}

Dari hasil perhitungan maka hasil perbandingan koefisien perpindahan panas secara keseluruhan (U) dapat ditulis pada gambar 10. Dari gambar 10 grafik di atas menunjukkan bahwa koefisien perpindahan panas menyeluruh pada tube aluminium adalah sebesar $12021 \mathrm{~W} / \mathrm{m}^{2} .{ }^{0} \mathrm{C}$ lebih kecil dibandingkan koefisien perpindahan panas secara menyeluruh pada tube tembaga adalah sebesar $12227 \mathrm{~W} / \mathrm{m}^{2} .{ }^{0} \mathrm{C}$, hal ini disebabkan oleh nilai dari konduktivitas material untuk tube tembaga lebih besar dari aluminium yaitu $\left(\mathrm{k}_{\mathrm{cu}}=384 \mathrm{~W} / \mathrm{m}^{0} \mathrm{C}\right)$ dan $\left(\mathrm{k}_{\mathrm{Al}}=310 \mathrm{~W} / \mathrm{m}^{0} \mathrm{C}\right)$. 


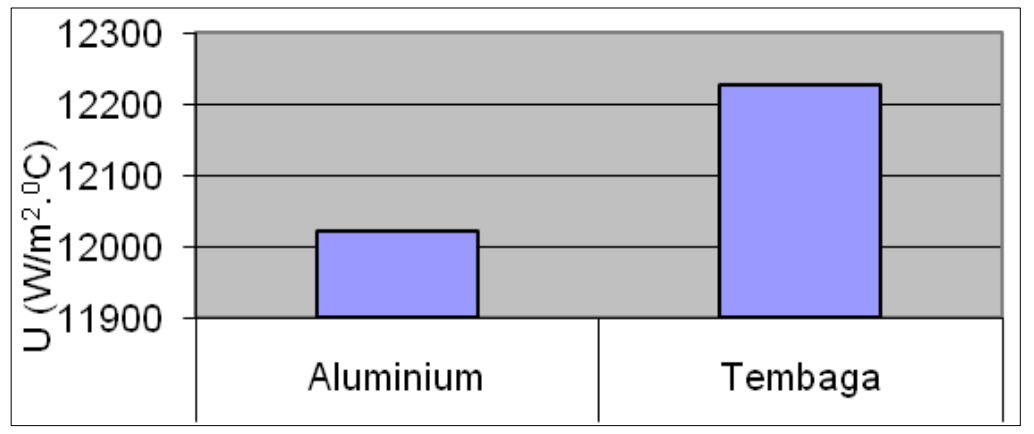

GAMBAR 10. Grafik perbandingan koefisien perpindahan panas menyeluruh pada tube tembaga dan aluminium.

Dari hasil perhitungan dengan menggunakan metode LMTD, maka hasil perbandingan laju perpindahan panas antara tube aluminium dan tembaga dapat dilihat pada gambar 11.

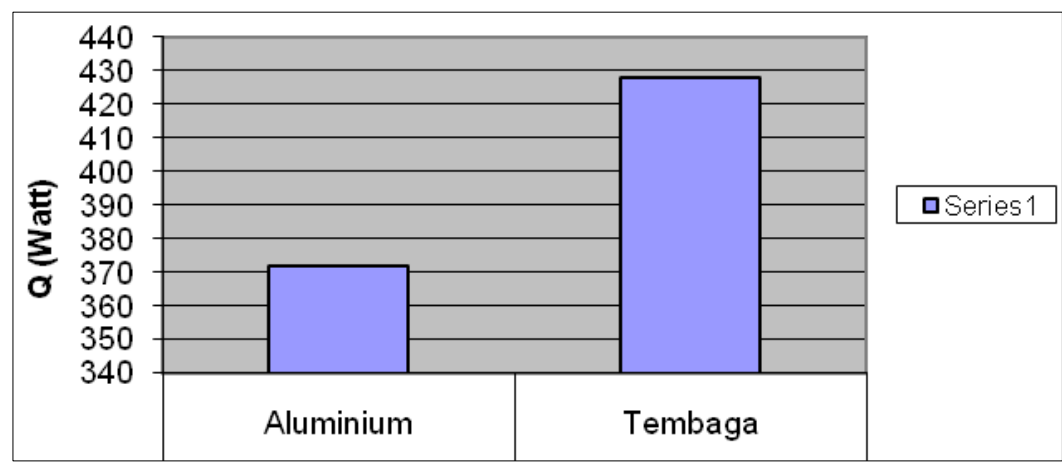

GAMBAR 11. Grafik hasil perbandingan laju perpindahan panas antara tube aluminium dan tembaga pada alat penukar kalor tipe shell and tube dengan metode LMTD.

Dari gambar 11, grafik, menunjukkan bahwa laju perpindahan panas pada aluminium lebih kecil dibandingkan laju perpindahan panas. Hal ini disebabkan oleh selisih temperatur rata-rata pada alat penukar kalor dengan tube yang terbuat dari tembaga lebih besar daripada alat penukar kalor yang terbuat dari aluminium.

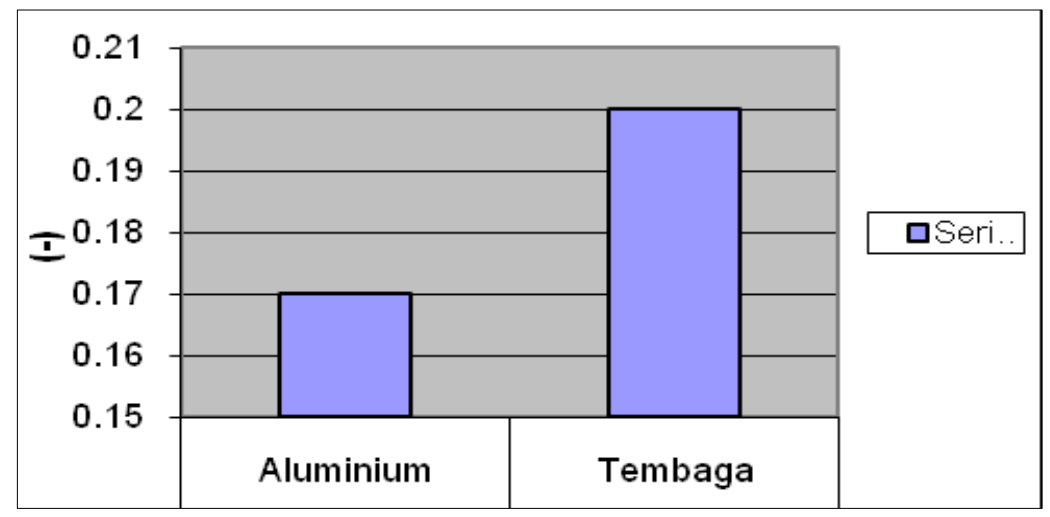

GAMBAR 12. Grafik perbandingan nilai efektivitas $(\varepsilon)$ pada tube alumunium dan tembaga pada alat penukar kalor tipe shell and tube dengan aliran berlawanan.

Dari gambar 12, grafik menunjukkan bahwa nilai efektivitas tembaga lebih besar dibandingkan dengan nilai efektivitas alumunium. Hal ini disebabkan oleh nilai NTU (Number of Transfer Unit). Nilai NTU tembaga lebih besar dibandingkan nilai NTU aluminium. Dari hasil perhitungan, diperoleh hasil perbandingan nilai NTU (Number of Transfer Unit) dapat dilihat grafik pada gambar 13. 


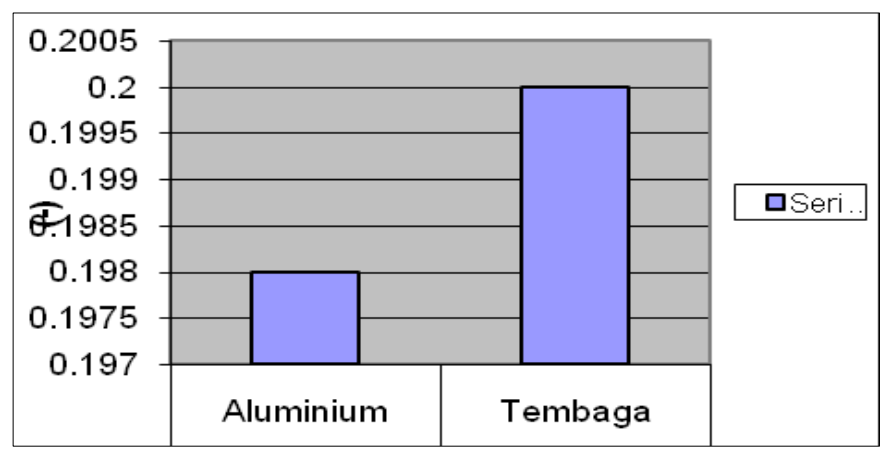

GAMBAR 13. Grafik perbandingan nilai NTU (Number of Transfer Unit) pada tube aluminium dan tembaga pada alat penukar kalor tipe shell and tube aliran berlawanan.

Dari gambar 13, grafik menunjukkan bahwa NTU (Number of Transfer Unit) pada tube aluminium lebih kecil dibandingkan NTU pada tube tembaga. Hal ini disebabkan oleh koefisien perpindahan panas menyeluruh pada tembaga lebih besar dibandingkan dengan koefisien perpindahan panas menyeluruh pada alumunium.

Dari hasil perhitungan dengan menggunakan metode NTU (Number of Transfer Unit), maka hasil perbandingan laju perpindahan panas antara tube aluminium dengan tube tembaga.

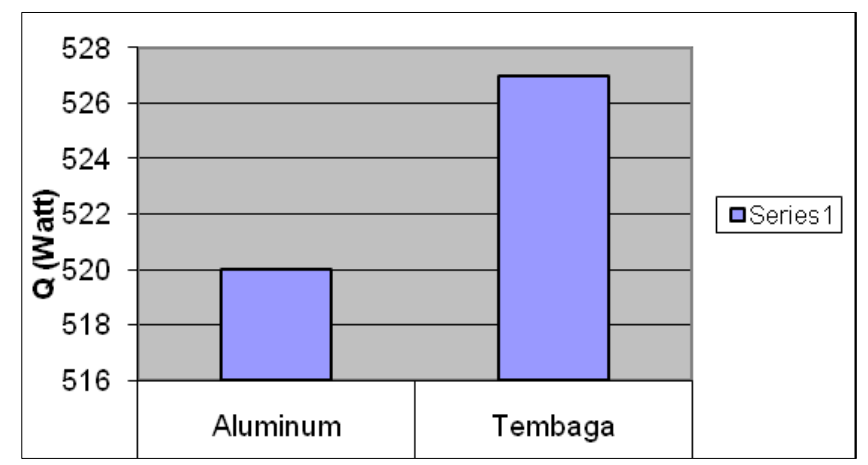

GAMBAR 14. Grafik hasil perbandingan laju perpindahan panas (q) antara tube aluminium dan tembaga pada alat penukar kalor tipe shell and tube.

Dari gambar 14, grafik menunjukkan bahwa laju perpindahan panas pada tube aluminium lebih kecil dibandingkan dengan laju perpindahan panas pada tube tembaga. Hal ini disebabkan oleh selisih temperatur rata-rata minimum pada alat penukar kalor dengan tube yang terbuat dari tembaga lebih besar dibandingkan dengan tube yang terbuat dari aluminium.

\section{KESIMPULAN}

Berdasarkan hasil pengamatan dan pengujian alat penukar kalor tipe shell and tube dengan tube aluminium dan tembaga untuk bentuk pitch segiempat, maka dapat disimpulkan bahwa hasil perhitungan untuk tube aluminium diperoleh koefisien perpindahan panas menyeluruh $(\mathrm{U})=$ $12021 \mathrm{Watt} / \mathrm{m}^{2}{ }^{0} \mathrm{C}$, selisih suhu rata-rata logaritmik (LMTD) $=9,8652{ }^{\circ} \mathrm{C}$, laju perpindahan panas (Q) dengan metode LMTD $=372,364$ Watt, Number of Transfer Unit (NTU) $=0,198$, efektivitas $(\varepsilon)=0,17$ dan laju perpindahan panas $(\mathrm{Q})$ dengan metode NTU-efektivitas $=520$ Watt.

Sedangkan hasil perhitungan untuk tube tembaga, diperoleh koefisien perpindahan panas menyeluruh $(\mathrm{U})=12227 \mathrm{Watt} / \mathrm{m}^{2} .{ }^{\circ} \mathrm{C}$, selisih suhu rata-rata logaritmik $(\mathrm{LMTD})=11,1357{ }^{\circ} \mathrm{C}$, laju perpindahan panas (Q) dengan metode LMTD $=427,5409$ Watt, Number of Transfer Unit $(\mathrm{NTU})=0,20$, Efektivitas $(\varepsilon)=0,2$ dan laju perpindahan panas $(\mathrm{Q})$ dengan metode NTUefektivitas $=527$ Watt.

Untuk hasil perhitungan dari pengujian dan pengamatan, dengan metode LMTD menunjukkan bahwa laju perpindahan panas pada tube tembaga $\left(\mathrm{Q}_{\mathrm{cu}}\right)=427,5409$ Watt lebih besar daripada 
laju perpindahan panas pada tube aluminium $\left(\mathrm{Q}_{\mathrm{al}}\right)=372,364$ watt. Hal ini disebabkan adanya selisih temperatur rata-rata pada alat penukar kalor dengan tube yang terbuat dari aluminium dan tembaga.

Dengan demikian dapat ditarik kesimpulan bahwa dari pengamatan laju perpindahan panas dengan metode NTU-efektivitas, menunjukkan bahwa laju perpindahan panas tube tembaga $\left(\mathrm{Q}_{\mathrm{cu}}\right)=527$ Watt lebih besar dibandingkan dengan tube Alumunium $(\mathrm{Qal})=372,364 \mathrm{watt}$. Hal itu disebabkan oleh adanya selisih temperatur rata-rata minimum pada alat penukar kalor dengan tube terbuat dari tembaga yang memiliki sifat pengantar panas yang baik lebih besar dibandingkan dengan tube alumunium.

\section{DAFTAR PUSTAKA}

[1] J.P. Holman, "Perpindahan Kalor", Edisi Keenam. Erlangga. Jakarta. 1997

[2] Coker Kayode A. "Fortran Program for Chemical Process Design Analysis and Simulation", Texas. 1995

[3] Kreith F. "Prinsip-prinsip Perpindahan Panas", Edisi Ketiga. Erlangga. Jakarta. 1994

[4] D.T. Sony Tjahyani. "Teknik Penukar Kalor", Jakarta. 2003.

[5] Chengel, Yunus A, "Heat Transfer", McGraw-Hill, New York, 2007

[6] Incropera, Frank P., dan Dewitt, David P., Fundamental of Heat and Mass Transfer", $4^{\text {th }}$ Edition, John Wiley and Sons, United States of America, 1996

[7] Lienhard, John H, "Heat Traansfer". Prentice-Hall Inc., New Jersey, 1987

[8] "Standards of The Tubular Exchanger Manufakturers Association", 9 $9^{\text {th }}$ edition, Tarrytown, New York 10591, 2007

[9] Ekadewi A. Handoyo, 2000, Pengaruh Kecepatan Aliran Terhadap Efektivitas Shell and Tube Heat Exchanger, Jurnal Teknik Mesin Universitas Kristen Petra, Jakarta.

[10] Wahyu S. Nugroho, 2001, Analisa Fouling Factor Pada Heat Exchanger Di Pembangkit Listrik Tenaga Uap Sektor Muara Karang Dengan Menggunakan Program Visual Basic 5.0, Tugas Akhir Universitas Trisakti, Jakarta.

[11] Joko P. Witoko, 2002, Pembuatan Penukar Panas Tipe Cangkang dan Tabung "SEPHIAK”, Jurnal P2TKN - BATAN, Jakarta.

[12] Warren M. Rohsenow, 1998, Handbook Heat Transfer, Mc Graw-Hill Handbook, New York. 